\title{
EML4-ALK-Positive Pulmonary Adenocarcinoma with an Unusual Metastatic Pattern: A Case Report
}

\author{
Stefan Diem ${ }^{a} \quad$ Martin Früh ${ }^{a} \quad$ Regulo Rodriguez $^{b} \quad$ Peter Liechti $^{c}$ \\ Christian Rothermundt ${ }^{a}$ \\ Departments of ${ }^{\mathrm{a}}$ Medical Oncology and ${ }^{\mathrm{b}}$ Pathology, Cantonal Hospital St. Gallen, \\ St. Gallen, and 'Doctor's Office, Sargans, Switzerland
}

\section{Key Words}

Lung cancer $\cdot$ ALK mutation · Gastric metastasis

\begin{abstract}
Background: Non-small cell adenocarcinoma is a frequent tumour entity with a high mortality. Insight into molecular mechanisms has led to the development of promising therapeutic options, which improve the prognosis of affected patients. There are only a few reports on molecular tumour subtypes and clinical presentation of the disease. We present the case of a patient with anaplastic lymphoma kinase (ALK)-positive adenocarcinoma of the lung with an unusual metastatic pattern. Conclusion: The metastatic pattern of non-small cell lung cancer with ALK translocation may be different from other lung cancers. An uncommon clinical presentation may sensitize treating physicians to perform corresponding molecular testing in order to offer the best treatment options.
\end{abstract}

(c) 2013 S. Karger AG, Basel

\section{Introduction}

An otherwise healthy, 62-year-old, non-smoking Caucasian woman had been complaining of postprandial, partly colicky epigastric pain for 2 months. She reported a weight loss of $1.5 \mathrm{~kg}$ over the past few weeks despite a normal appetite. A clinical examination was unremarkable and her family history was negative for malignancies.

Gallstones were detected on abdominal ultrasound. Upper endoscopy showed a small gastric hernia but no signs of gastroesophageal reflux disease. A non-specific lesion adjacent to the cardia was biopsied (fig. 1). The gastric biopsy revealed adenocarcinoma. Immuno- 
histochemical staining showed strong expression of TTF-1 and cytokeratins 7 and 20 . These findings were consistent with metastasis from primary lung cancer. A chest CT showed two masses, 23 and $9 \mathrm{~mm}$ in diameter, in the right upper lobe, and hilar lymphadenopathy. On bronchoscopy, no endoluminal tumour was seen; however, cytology from the mediastinal lymph nodes was consistent with the same adenocarcinoma found in the stomach (positivity for TTF-1 and cytokeratin 20). Magnetic resonance imaging of the brain revealed multiple, asymptomatic supra- and infratentorial metastases up to $22 \mathrm{~mm}$ in diameter. A bone scan showed no evidence of skeletal metastases.

Epidermal growth factor receptor mutation analysis on the gastric biopsy was negative for exons 18-21, but anaplastic lymphoma kinase (ALK) rearrangement was positive on fluorescence in situ hybridization: an ALK fusion transcript was detected in 55\% of the tumour cells (fig. 2).

Treatment comprised whole-brain radiotherapy followed by platinum-based chemotherapy, resulting in stable disease and symptomatic improvement of abdominal pain. After 2 months, progression in the form of new liver metastases was noted on a CT scan, and the patient was enrolled in an expanded access program and treated with the ALK inhibitor crizotinib. The patient's tumour-associated symptoms (i.e. anorexia and asthenia) improved considerably within 2 weeks, and tumour response was seen on a CT scan and endoscopy (fig. 3) after 6 weeks of treatment. To date, the patient is doing well with no evidence of progression after having been treated with crizotinib for 9 months.

\section{Discussion}

We present the unusual case of a patient with ALK-positive adenocarcinoma of the lung who presented with a symptomatic gastric metastasis. There is an approximate $4 \%$ incidence of ALK rearrangement in a certain non-small cell lung cancer (NSCLC) population [1-5]. However, the incidence is significantly higher (up to $22 \%$ ) in young, non-smoking patients with advanced tumour stage [6].

The most common localisations of extrapulmonary metastases in lung cancer are the liver, bones, adrenal glands and brain [7]. The incidence of metastases to the gastrointestinal tract has been reported to be as high as $11.9 \%$ for the entire gastrointestinal tract [7-9] and $1.7-5.1 \%$ for gastric metastases found on autopsy $[9,10-12]$. Interestingly, the incidence of symptomatic gastrointestinal lesions is only $0.2-1.77 \%[7,13,14]$. Thus, gastric metastases either occur late during the course of the disease or are occult.

A recent publication has demonstrated a correlation between the molecular oncogene status and the biological behaviour in NSCLC, resulting in distinct metastatic patterns [15]. A total of 209 patients with stage IV NSCLC were assessed for ALK rearrangement, epidermal growth factor receptor and v-Ki-ras2 Kirsten rat sarcoma viral oncogene homolog (KRAS) mutational status. Compared to those patients with triple-negative tumours, the ALKpositive patients showed a significant association with pleural, pericardial and liver metastases. Of note, patients with ALK gene rearrangement were found to have more metastatic sites affected at initial diagnosis when compared to those with triple-negative tumours, again indicating a different biological behaviour and metastatic pattern of this disease. These findings underpin our case, as gastric metastases are commonly indicative of a more advanced disease stage. Although the prognostic significance of ALK positivity currently remains unclear, these observations would assume a more aggressive natural disease course. 
Diem et al.: EML4-ALK-Positive Pulmonary Adenocarcinoma with an Unusual Metastatic Pattern: A Case Report

\section{Conclusion}

To the best of our knowledge, clinical presentation with a symptomatic gastric metastasis in an ALK-positive lung cancer patient has not been reported to date. This supports other observations that the metastatic pattern of this particular NSCLC subtype is different from that of other lung cancers. Apart from patient and tumour characteristics associated with the presence of an ALK translocation (i.e. never or former smoker, young age, adenocarcinoma and frequent liver, pleural and pericardial metastases), an uncommon clinical presentation may also sensitise treating physicians to the need to perform corresponding molecular testing in order to offer the best treatment option.

\section{References}

1 Soda M, Choi YL, Enomoto M, Takada S, Yamashita Y, Ishikawa S, Fujiwara S, Watanabe H, Kurashina K, Hatanaka H, Bando M, Ohno S, Ishikawa Y, Aburatani H, Niki T, Sohara Y, Sugiyama Y, Mano H: Identification of the transforming EML4-ALK fusion gene in non-small-cell lung cancer. Nature 2007;448:561-566.

-2 Rikova K, Guo A, Zeng Q, Possemato A, Yu J, Haack H, Nardone J, Lee K, Reeves C, Li Y, Hu Y, Tan Z, Stokes M, Sullivan L, Mitchell J, Wetzel R, Macneill J, Ren JM, Yuan J, Bakalarski CE, Villen J, Kornhauser JM, Smith B, Li D, Zhou X, Gygi SP, Gu TL, Polakiewicz RD, Rush J, Comb MJ: Global survey of phosphotyrosine signaling identifies oncogenic kinases in lung cancer. Cell 2007;131:1190-1203.

3 Koivunen JP, Mermel C, Zejnullahu K, Murphy C, Lifshits E, Holmes AJ, Choi HG, Kim J, Chiang D, Thomas R, Lee J, Richards WG, Sugarbaker DJ, Ducko C, Lindeman N, Marcoux JP, Engelman JA, Gray NS, Lee C, Meyerson M, Jänne PA: EML4-ALK fusion gene and efficacy of an ALK kinase inhibitor in lung cancer. Clin Cancer Res 2008;14:4275-4283.

-4 Wong DW, Leung EL, So KK, Tam IY, Sihoe AD, Cheng LC, Ho KK, Au JS, Chung LP, Pik Wong M: The EML4ALK fusion gene is involved in various histologic types of lung cancers from non-smokers with wild-type EGFR and KRAS. Cancer 2009;115:1723-1733.

-5 Takeuchi K, Choi YL, Soda M, Inamura K, Togashi Y, Hatano S, Enomoto M, Takada S, Yamashita Y, Satoh Y, Okumura S, Nakagawa K, Ishikawa Y, Mano H: Multiplex reverse transcription-PCR screening for EML4-ALK fusion transcripts. Clin Cancer Res 2008;14:6618-6624.

-6 Shaw AT, Yeap BY, Mino-Kenudson M, Digumarthy SR, Costa DB, Heist RS, Solomon B, Stubbs H, Admane S McDermott U, Settleman J, Kobayashi S, Mark EJ, Rodig SJ, Chirieac LR, Kwak EL, Lynch TJ, Iafrate AJ: Clinical features and outcome of patients with nonsmall-cell lung cancer who harbor EML4-ALK. J Clin Oncol 2009;27:4247-4253.

7 Kim SY, Ha HK, Park SW, Kang J, Kim KW, Lee SS, Park SH, Kim AY: Gastrointestinal metastasis from primary lung cancer: CT findings and clinicopathologic features. AJR Am J Roentgenol 2009;193:W197-W201.

8 McNeill P, Wagman L, Neifeld J: Small bowel metastases from primary carcinoma of the lung. Cancer 1987;59:1486-1489.

-9 Yoshimoto A, Kasahara K, Kawashima A: Gastrointestinal metastases from primary lung cancer. Eur J Cancer 2006;42:3157-3160.

10 Ryo H, Sakai H, Ikeda T, Hibino S, Goto I, Yoneda S, Noguchi Y: Gastrointestinal metastasis from lung cancer (in Japanese). Nihon Kyobu Shikkan Gakkai Zasshi 1996;34:968-972.

-11 Antler AS, Ough Y, Pitchumoni CS, Davidian M, Thelmo W: Gastrointestinal metastases from malignant tumors of the lung. Cancer 1982;49:170-172.

$\checkmark 12$ Hasegawa N, Yamasawa F, Kanazawa M, Kawashiro T, Kikuchi K, Kobayashi K, Ishihara T, Kuramochi S, Mukai M: Gastric metastasis of primary lung cancer (in Japanese). Nihon Kyobu Shikkan Gakkai Zasshi 1993;31:1390-1396.

-13 Berger A, Cellier C, Daniel C, Kron C, Riquet M, Barbier JP, Cugnenc PH, Landi B: Small bowel metastases from primary carcinoma of the lung: clinical findings and outcome. Am J Gastroenterol 1999;94:1884-1887. Yang CJ, Hwang JJ, Kang WY, Chong IW, Wang TH, Sheu CC, Tsai JR, Huang MS: Gastro-intestinal metastasis of primary lung carcinoma: clinical presentations and outcome. Lung Cancer 2006;54:319-323.

15 Doebele RC, Lu X, Sumey C, Maxson DA, Weickhardt AJ, Oton AB, Bunn PA Jr, Barón AE, Franklin WA, Aisner DL, Varella-Garcia M, Camidge DR: Oncogene status predicts patterns of metastatic spread in treatmentnaïve nonsmall cell lung cancer. Cancer 2012;118:4502-4511. 


\section{Case Reports in Oncology}

\begin{tabular}{l|l}
\hline Case Rep Oncol 2013;6:316-319 \\
\hline DOI: $10.1159 / 000352086$ & $\begin{array}{l}\text { C 2013 S. Karger AG, Basel } \\
\text { www.karger.com/cro }\end{array}$ \\
\hline
\end{tabular}

Diem et al.: EML4-ALK-Positive Pulmonary Adenocarcinoma with an Unusual

Metastatic Pattern: A Case Report

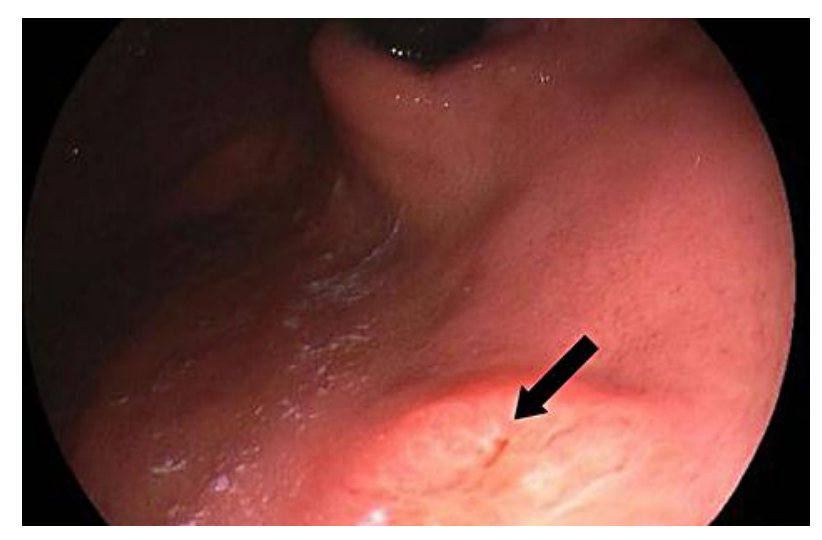

Fig. 1. Endoscopy reveals an ulcer in the cardia (arrow) before therapy.

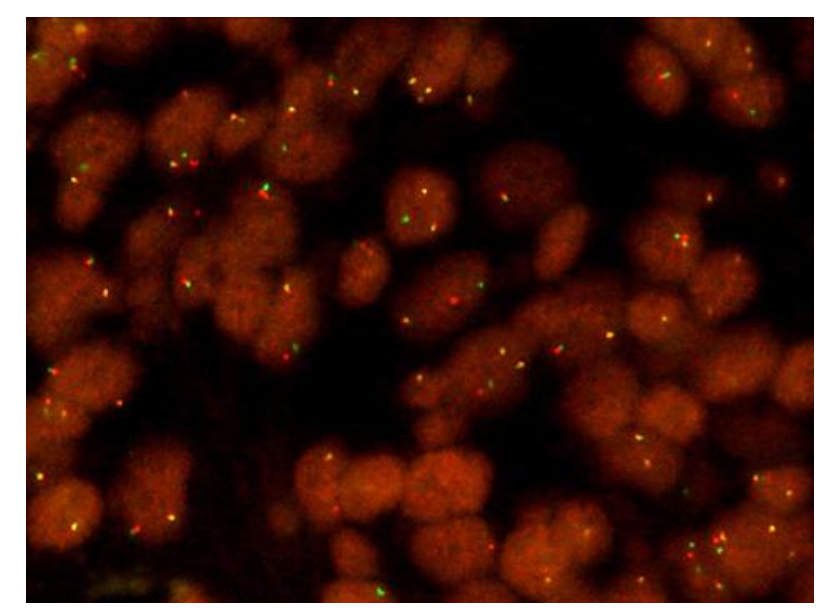

Fig. 2. EML4-ALK gene-positive translocation: split gene signal can be seen in $55 \%$ of the nuclei, with separate red and green signals (red signal: telomer side of the ALK gene, green signal: centromere side of the ALK gene).

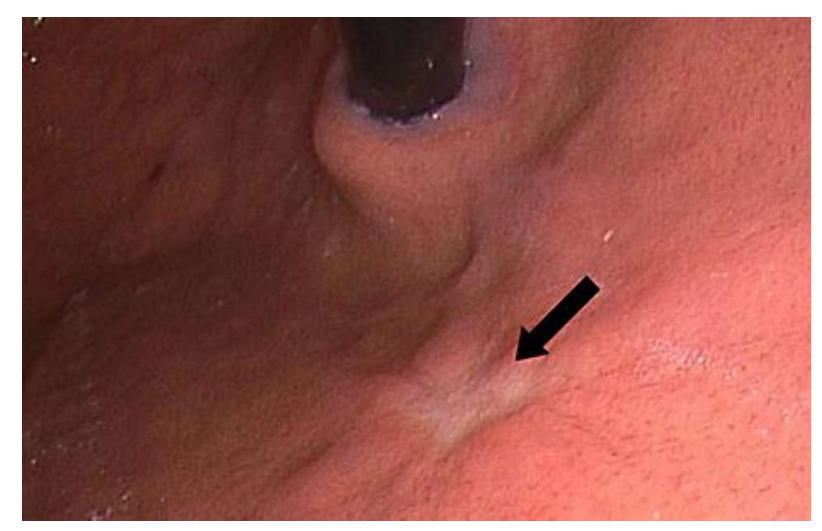

Fig. 3. Same ulcer as in figure 2 (arrow) after 6 cycles of cisplatin/pemetrexed and under continuous therapy with an ALK inhibitor. 